\title{
Analysis of factors influencing rural employment promotion for community development in Southern Nigeria
}

\author{
O. D. Kolawole \\ Department of Agricultural Extension and Rural Sociology, \\ Obafemi Awolowo University, Ile-Ife, Nigeria
}

\begin{abstract}
Some specific objectives of the paper were to describe and analyse the socio-economic characteristics of rural respondents; describe and analyse institutional, community, and ecological variables promoting rural employment; and estimate/determine crucial factors, which could influence rural employment promotion in Southern Nigeria. A multi-stage sampling procedure was used to select 60 rural communities in Southern Nigeria from which 300 interviewees were sampled and interviewed using structured and unstructured interview schedules. Simple descriptive statistical techniques such as frequency, percentages, mean, standard deviation, etc. were used to describe and summarise the data collected. Applying the law of Eigenvalue greater than or equal to 1, factor analysis was used to determine some crucial factors associated with employment promotion in Southern Nigeria. It was obvious from the results that over $50.0 \%$ of the variables that had some degrees of relationship with REP were identified in the study. Socio-economic, institutional, infrastructure variables were found to enhance the promotion of rural employment in the area. Basically, about five major factors were extracted in the process of variable reduction in the analysis of data. These are the socio-economic attributes of the respondent $(\lambda=2.328)$, institutional influence on his activities $(\lambda=2.177)$, the ecology of his immediate environment $(\lambda=1.390)$, his financial and knowledge acquisition $(\lambda=1.750)$ and the infrastructure $(\lambda=1.283)$ at his disposal for appropriation in the process of establishing a cottage industry for production and or service purpose(s).

Keywords: rural employment, socio-economic, institution, ecology, community, infrastructure, knowledge, infrastructure, environment, finance.
\end{abstract}




\section{Introduction}

There are a myriad of barriers facing rural supported employment programmes, headlong. "Systematic needs assessment surveys and focus groups reveal ongoing concerns from rural providers and consumers" [1-3]. Some of these include "a perceived lack of jobs and career advancement opportunities; a lack of adequate funding or funding incentives to increase supported employment; a lack of management and leadership training and technical assistance to support and guide community employment expansion and sheltered program downsizing; a lack of transportation options", etc.

The International Labour Organisation (ILO) at the $48^{\text {th }}$ session of its General Conference convened at Geneva in 1964 had, however, recommended amongst others that "Institutional measures for the promotion of productive employment in the rural sector should include agrarian reforms, adapted to the needs of the country, including land reform and improvement of land tenure; reform in methods of land taxation; extension of credit facilities; development of improved marketing facilities; and promotion of co-operative organisation in production and marketing". Realising these goals in addition to others would, in way, enhance rural community development.

To formulate a practicable and effective policy on rural employment promotion, therefore, a thorough understanding of factors associated with its enhancement amongst grassroots people needs be relied upon by policy-makers. Hence, the primary objectives of the paper were to describe and analyse the socio-economic, institutional, ecological and cultural variables promoting rural employment in the study area; and estimate/determine crucial factors, which could influence rural employment promotion in Southern Nigeria.

\section{Methodology}

\subsection{The study area}

Southern Nigeria comprises about 17 states. However, Ekiti, Ebonyi and Rivers States were randomly selected from the South-West, South-East and SouthSouth, respectively. The zones lie within the tropical rainforest belt and the people's primary occupation is farming.

\subsection{Sample selection and research instrument}

A multi-stage sampling procedure was used to select 60 rural communities in Southern Nigeria thus: About $25.0 \%$ of the 17 states (which translates to about 3 States) were purposively selected based on the ecology of the region. In essence, at least, one riverine State was selected out of the three. From the three selected states (Ebonyi, Ekiti and Rivers), about $25.0 \%$ of the rural Local Government Areas (LGAs) was randomly selected.

From the selected LGAs in each of the States, 20 rural communities were proportionately and purposively selected for the survey exercise, based on the 
number of communities in each LGA. About 100 respondents were, therefore, proportionately sampled from the 20 communities in each of the States, based on the population of each selected community. In all, 300 interviewees were sampled and interviewed in Southern Nigeria using structured and unstructured interview schedules. Primary data were collected through survey method. Testretest method was employed in determining the consistency/reliability of the instrument.

\subsection{Measurement of variables}

Two categories of variables (both dependent and independent variables) were operationalised in the study. Rural employment promotion (REP) served as the dependent variable against which other variables were operationalised. The dependent variable (Y) was measured by the average number of employees per rural based enterprise. All other independent variables (Xs) were either scored or coded depending on whether they are parametric or non-parametric variables, respectively. For instance, farm size was scored based on the number of hectare(s) put into use by a respondent; a male respondent was coded 1 while a female respondent was coded 0 ; age of respondents was scored based on the number of years lived; etc.

\subsection{Data analysis}

Simple descriptive statistical techniques such as frequency, percentages, and measures of central tendency and dispersion (mean and standard deviation) were used to describe and summarise the data collected. Factor analysis was employed to estimate or determine the crucial factors that influenced rural employment promotion in Southern Nigeria. The law of Eigenvalue greater than or equals to one (1) was used to extract principal components in the data. In the rotated factor matrix (see Table 1), the test of significance of the loadings was determined by the level of significance of the Pearson correlation coefficient. The principal components, whose factor loadings latent roots were greater than or equal to one $(\lambda \geq 1)$ were retained in the analysis. $\lambda$ is the summation of the squares of the significant loadings $\left(\varepsilon L^{2}\right)$ for each isolated factor.

\section{Results and discussions}

\subsection{Demographic and socio-economic attributes of respondents}

The average household size in Ebonyi State was 7.61 while Ekiti and Rivers States had 7.95 and 1.53, respectively. The average age of respondents in Ebonyi, Ekiti and Rivers States was 45.22, 52.42 and 43.0 years, respectively, too. Educationally, about $43.0 \%$ of respondents in both Ebonyi and Ekiti States either completed secondary school or even had tertiary education, while in Rivers State, about $44.0 \%$ of those sampled had secondary education just as $26.0 \%$ of this acquired tertiary education also. The average levels of income of the rural people interviewed in Ebonyi, Ekiti and Rivers States were N9, 700.00; N14, 981.80; and N13, 485.00 per month, respectively (About 130 Naira is 
equivalent to US\$1:00). Data also revealed that rural people's belongingness to association and participation was very low in Ebonyi, Ekiti and Rivers States! While most respondents in Ebonyi State had more access to information through friends and neighbours and market forums (100.0\%), and radio (94.0\%), those sampled in Ekiti State had more access to information through friends and neighbours $(98.0 \%)$, ADPs $(94.0 \%)$, market forums $(77.0 \%)$, radio $(73.0 \%)$ and television (44.0\%). Friends and neighbours and market forums $(100.0 \%)$, radio $(99.0 \%)$, television $(42.0 \%)$ and newspapers (32.0\%) were major sources of information for the ruralites in Rivers State.

Table 1: $\quad$ Rotated factor matrix for socio-economic factors, ecological factors and institutional factors associated with REP in Southern Nigeria.

\begin{tabular}{|l|c|c|c|c|c|}
\hline Variable & Factor 1 & Factor 2 & Factor 3 & Factor 4 & Factor 5 \\
\hline Age & $0.871^{*}$ & 0.003 & 0.000 & -0.129 & -0.001 \\
\hline Household & $0.833^{*}$ & -0.009 & -0.006 & 0.225 & -0.004 \\
\hline Cosmopoliteness & $0.606^{*}$ & 0.296 & 0.287 & 0.131 & 0.149 \\
\hline Farm size with & $0.570^{*}$ & 0.279 & 0.291 & 0.150 & 0.104 \\
\hline $\begin{array}{l}\text { Contact } \\
\text { govt. agencies }\end{array}$ & 0.162 & $0.748^{*}$ & 0.249 & 0.286 & 0.010 \\
\hline Govt. Support & 0.126 & $0.687^{*}$ & 0.306 & 0.007 & 0.158 \\
\hline $\begin{array}{l}\text { Source of water } \\
\text { supply }\end{array}$ & -0.225 & $-0.627^{*}$ & -0.168 & 0.200 & 0.001 \\
\hline Family support & 0.121 & $-0.578^{*}$ & 0.187 & -0.003 & $0.462^{*}$ \\
\hline $\begin{array}{l}\text { Banking } \\
\text { facilities }\end{array}$ & -0.004 & $0.425^{*}$ & -0.292 & 0.007 & 0.003 \\
\hline Rainfall pattern & -0.201 & 0.185 & $-0.821^{*}$ & 0.005 & 0.002 \\
\hline $\begin{array}{l}\text { Community } \\
\text { support }\end{array}$ & 0.004 & 0.001 & $0.650^{*}$ & 0.005 & $-0.426^{*}$ \\
\hline Soil type & -0.003 & 0.003 & $0.542^{*}$ & 0.005 & 0.008 \\
\hline Education level & -0.170 & 0.111 & 0.010 & $0.813^{*}$ & -0.002 \\
\hline Income & $0.428^{*}$ & 0.167 & -0.175 & $0.640^{*}$ & -0.002 \\
\hline $\begin{array}{l}\text { Information } \\
\text { source(s) }\end{array}$ & 0.003 & 0.008 & -0.008 & $0.503^{*}$ & -0.177 \\
\hline $\begin{array}{l}\text { Rural } \\
\text { employment } \\
\text { promotion }\end{array}$ & 0.328 & 0.007 & 0.003 & $0.483^{*}$ & 0.108 \\
\hline $\begin{array}{l}\text { Association } \\
\text { membership }\end{array}$ & 0.008 & -0.129 & 0.278 & $0.439^{*}$ & 0.008 \\
\hline $\begin{array}{l}\text { Motorable } \\
\text { road(s) }\end{array}$ & 0.009 & 0.007 & 0.000 & -0.003 & $0.790^{*}$ \\
\hline $\begin{array}{l}\text { Electricity } \\
\text { source(s) }\end{array}$ & -0.007 & $0.487^{*}$ & -0.162 & -0.005 & $0.514^{*}$ \\
\hline Source: Field Survey & 2005 & & & & \\
\hline
\end{tabular}

Source: Field Survey, 2005.

All loadings (a) significant at $\mathrm{P} \leq 0.01$ level. 
Farming was rated as having the highest occurrence in rural Ebonyi $(72.0 \%)$, Ekiti (100.0\%) and Rivers (38.0\%). Trading (46.0\%) and civil service $(17.0 \%)$ followed farming, in that order, in Ebonyi State. Civil service (24.0\%) and transportation business $(20.0 \%)$ were relatively more prominent in the rural communities of Rivers State after farming. The average farm size was 2.80, 5.10 and 1.43 hectare in Ebonyi, Ekiti and Rivers States, respectively. In terms of outside orientation, respondents $(75.0 \%)$ in Ebonyi State were more cosmopolitan than their counterparts in either Ekiti or Rivers, where only 22.0 and $14.0 \%$ "had travelled to other towns outside the State", respectively.

\subsection{Institutional and communal support, ecology and project orientation}

This section explains the support or forms of assistance provided for rural people (either at the government, community or family level) in the States investigated to enable them promote rural employment. Analysis showed that about 88.0 and $100.0 \%$ of those sampled opined that "Government has not funded any individual or group project that promotes rural employment" in Ebonyi and Rivers States, respectively. However, about 39.0\% of Ekiti respondents were of the same opinion. Majority of the people in Ebonyi, Ekiti and Rivers State claimed that their family members supported them morally in their business ventures. A relatively substantial percentage acknowledged financial and labour support from their family members in all the States. Except for Ekiti and Rivers States, where less than $50.0 \%$ of those interviewed claimed their communities had provided land for them, cultural and other support were fully given a substantial percentage of respondents in all the three States investigated.

It was affirmed that "Soil strongly supports farming" in the States of Ebonyi $(100.0 \%)$, Ekiti $(100.0 \%)$ and Rivers $(84.0 \%)$. About $93.0 \%$ of respondents in Rivers claimed that rainfall was heavy throughout the year while rainfall is heavy in some months of the year in both Ebonyi and Ekiti States (100.0\%). Rural business ventures in Ekiti (53.0\%) and Rivers (65.0) were productionbased unlike in Ebonyi State, where both service and production were said to be the thrusts of projects/businesses. In most cases, capital outlay was small. Only about $27.0 \%$ of the people said their capital outlay was moderate. Majority also claimed that their project is appropriate to the locality. While only about $5.0 \%$ saw lack of market, labour and raw materials as impediments to the appropriateness of projects in rural communities of Rivers State, just about $3.0 \%$ in Ebonyi State had the same perception. The average number of people employed by rural entrepreneurs in Ebonyi, Ekiti and Rivers States was 2.00, 1.64 and 0.91 , respectively.

\subsection{Factor analysis}

Data in Table 1 presented the results of varimax factor rotation pattern with the variables/measures that were highly loaded on each of the five factors extracted. Table 2 indicated that five factors were conveniently extracted based on the law of "Eigenvalue greater than or equal to one (1)", just as factors that accounted for the variance greater than 1 were considered. 
Table 2: $\quad$ Principal component analysis of independent variables (socioeconomic, institutional, ecological and community related factors) associated with REP in Southern Nigeria.

\begin{tabular}{|l|l|l|l|}
\hline Factor names & Eigen value & $\begin{array}{l}\text { Percentage } \\
\text { of variance }\end{array}$ & $\begin{array}{l}\text { Cumulative } \\
\text { percentage of } \\
\text { variance }\end{array}$ \\
\hline $\begin{array}{l}\text { 1.Socio- } \\
\text { economic } \\
\text { attributes }\end{array}$ & 3.803 & 20.01 & 20.01 \\
\hline $\begin{array}{l}\text { 2.Institutional } \\
\text { influence }\end{array}$ & 2.001 & 10.53 & 30.54 \\
\hline 3.Ecology and & 1.708 & 9.45 & 40.00 \\
\hline $\begin{array}{l}\text { 4.Financial knowledge } \\
\text { acquisition }\end{array}$ & 8.99 & 48.99 \\
\hline 5.Infrastructure & 1.210 & 6.37 & 55.35 \\
\hline $\begin{array}{l}\text { 6.Other unknown } \\
\text { factors }\end{array}$ & - & 44.65 & 100.0 \\
\hline
\end{tabular}

Source: Field survey, 2005.

The summation of the square of loadings $\left(\sum \mathrm{L}^{2}\right)$ of each of the significant variables under each factor as presented in Table 2 gave the latent root of the factor. With respect to Factor one $(1)$, for instance, age $(\mathrm{L}=0.871)$, household size $(\mathrm{L}=0.833)$, cosmopoliteness $(\mathrm{L}=0.606)$, farm size $(\mathrm{L}=0.570)$, income $(\mathrm{L}$ $=0.428$ ) were major contributors to the naming of Socio-economic attributes of rural entrepreneurs. The summation of the square of the loadings (significant contributory variables), therefore, gave the latent root $(\lambda)$ value. Therefore, $\sum \mathrm{L}^{2}$ of Factor 1 is given as $\lambda=2.328$. Institutional influence had a latent $\operatorname{root} \lambda=$ 2.177. Factor 3 (ecology) had a latent root $\lambda$ of 1.390 . Also, factor 4 , Financial and knowledge acquisition was ascribed a latent root $(\lambda)$ value of 1.750 . Infrastructure had a latent root $\lambda$ value of 1.283 . This seems to have buttressed the earlier claim of Kolawole and Torimiro [4], who submitted that social status, personal experience and infrastructure functionality, among others, were crucial factors in the drive towards rural employment promotion for grassroots transformation. Functional infrastructure, as it were, is a crucial component of community development.

Data in Table 2 gave the percentage of variation and Eigenvalue of each contributing factor. The percentage variations in the drive towards participation in REP as attributable to each of the factor component were computed in descending order of contribution as socio-economic attributes of an individual (20.01\%); institutional influence (10.53\%); ecology (9.45\%); financial and knowledge acquisition (8.99\%); infrastructure (6.37\%); and other unknown factors $(44.65 \%)$. In essence, the identified five major factors had about $55.35 \%$ influence on the drive towards effective participation in REP in Southern Nigeria. 


\section{Conclusions and recommendations}

Essentially, five major factors were extracted from about eighteen variables in the process of variable reduction. These are the socio-economic attributes of the respondent, institutional influence on his activities, the ecology of his immediate environment, his financial and knowledge acquisition and the infrastructure at his disposal for appropriation in the process of establishing a cottage industry for production and or service purpose(s). Socio-economic variables (such household size, education level, income, external orientation/cosmopoliteness, contact with government agencies, association membership, information source(s) and farm size); availability of infrastructural facilities (such as electricity supply, motorable roads, and bank availability); and institutional influence as reflected in government, family and community support have been found as crucial to the enhancement of employment promotion in Southern Nigeria [5]. It is thus clear from the analysis that the three key elements in promoting rural employment are the people themselves, the government and the immediate environment in which the prospective entrepreneur is situated. However, it is the onus of the government to set in motion enabling situations that allow for self expression of the typical rural businessman.

The formulation and implementation of appropriate policies and programmes - that are relevant to the needs and aspirations of the rural man to enable him realise his full potential for progress and emancipation - would enhance sustainable community development. It is, therefore, essential to ensure that making available basic and functional services such as education, health care, water, electricity and motorable roads are vital for rural employment promotion drive in rural communities. It is, thus, the onus of the government to make this infrastructure available as a take-off point for jump starting employment promotion for sustainable livelihood.

Providing vital information as they relate to government services and performance in the public circle and putting in place mechanisms for poor people's inclusion and participation is sine qua non for rural employment promotion and community development.

Putting in place appropriate projects, which are self sustaining, need to be identified for particular localities as reflected in this study to ensure economies of scale and continuity of operations. The important roles of the grassroots people in decision-making are considered crucial for sustainable rural community development.

\section{Acknowledgement}

The author acknowledges the F.S. Idachaba Foundation for Research and Scholarship (IFRES) for funding the original research from which this paper is drawn. 


\section{References}

[1] Griffin, C.C., Region VIII training needs survey, Greely, CO: CTAT/UNC, 1995.

[2] Griffin, C.C., Montana state-wide training needs assessment, Missoula, MT: The Rural Institute/The University of Montana, 1997a.

[3] Griffin, C.C., National supported employment focus group, APSE Conference, Orlando, Florida, 1997b.

[4] Kolawole, O.D. and Torimiro, D.O., Participatory rural entrepreneurship development for grassroots transformation: A factor analysis, Journal of Human Ecology, 18 (3), pp. 193-198, 2005.

[5] Kolawole, O.D., Rural employment promotion in Southern Nigeria, Research Report, Idachaba Foundation for Research and Scholarship (IFRES), Ibadan, Nigeria, pp. 1-65, 2006. 